\title{
L1 marginalisation in Japan
}

DOI:

10.1080/14664208.2019.1647998

\section{Document Version}

Accepted author manuscript

Link to publication record in Manchester Research Explorer

\section{Citation for published version (APA):}

Noda, M., \& O'Regan, J. P. (2019). L1 marginalisation in Japan: monolingual instrumentalism and the discursive shift against yakudoku in the Japanese government's Course of Study. Current Issues in Language Planning. https://doi.org/10.1080/14664208.2019.1647998

\section{Published in:}

Current Issues in Language Planning

\section{Citing this paper}

Please note that where the full-text provided on Manchester Research Explorer is the Author Accepted Manuscript or Proof version this may differ from the final Published version. If citing, it is advised that you check and use the publisher's definitive version.

\section{General rights}

Copyright and moral rights for the publications made accessible in the Research Explorer are retained by the authors and/or other copyright owners and it is a condition of accessing publications that users recognise and abide by the legal requirements associated with these rights.

\section{Takedown policy}

If you believe that this document breaches copyright please refer to the University of Manchester's Takedown Procedures [http://man.ac.uk/04Y6Bo] or contact uml.scholarlycommunications@manchester.ac.uk providing relevant details, so we can investigate your claim.

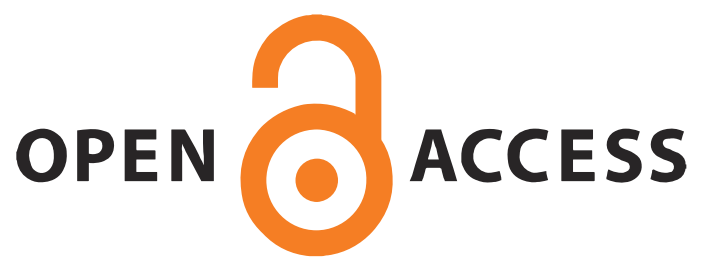




\section{L1 marginalisation in Japan: monolingual instrumentalism and the discursive shift against yakudoku in the Japanese government's Course of Study}

Mamiko Noda, John P. O’Regan

This article focuses upon the Japanese government's decision in 2009 to direct an 'English-only' strategy for English language education in senior high schools from 2013. In the Course of Study 2009, and more recently again in the Course of Study 2018 , the Japanese government implicitly blames the local grammar-translation method of teaching, known as yakudoku, for the failure of teachers to foster their students' English proficiency, and suggests that it should be replaced 'in principle' by Englishonly classes. This article examines how the policy originated and was then formulated in the Course of Study 2009, and how local teachers received it. In order to investigate stakeholders' perspectives regarding the use of yakudoku and its replacement by an instrumentalist strategy, a three-month discourse-oriented ethnographic field study was conducted in Japan. The data were then scrutinised using a critical discourse analysis methodological framework (Fairclough, 1992, 2003). This article makes the argument that the term yakudoku has been manipulated by the Japanese government for the purposes of marginalising the use of Japanese in the classroom and of instituting its preference for a western-centric model of learning for the teaching of English in schools.

Key words: Critical Discourse Analysis, monolingualism, yakudoku, TESOL, language policy

The use of L1 in the English as a foreign classroom has since the late nineteenth century undergone a process of marginalisation in applied linguistics, especially in the pedagogic fields of SLA (Second Language Acquisition) and TESOL. This has been well documented in the academy (G. Cook, 2010; V. Cook, 2001; G. Hall \& G. Cook, 2012). In this article, we argue that in English language teaching (henceforth ELT), the result has been the structuring in dominance (Althusser, 1965/1996) of an ideology of monolingual instrumentalism according to which the native-speaker-derived model of English is given priority in the 
classroom, and the L2 competence of learners is neglected or even actively suppressed (cf. Kubota, 2011a; May, 2011; van Splunder, 2016). In Althusser's description of this relation, in such an ideology, 'the complex whole has the unity of a structure in dominance' (1965/1996, p. 204), and it is this which 'accounts for the very structure of the whole' (p. 205). In this article, we refer to this ideological structuring in the Japanese English classroom as being one of monolingual instrumentalism, according to which English is given an overarching priority in relation to Japanese, which is in turn rendered taboo.

The instrumentalist ideology in SLA and TESOL has had a pervasive influence on English language pedagogy in many parts of the world, particularly in East Asia (Higuchi et al., 2005; Liu, Ahn, Baek \& Han, 2004). In response to Japan's relative decline in economic power since the early 1990s, especially in comparison with its closest Asian neighbours, the Japanese government repeatedly announced its intention to introduce changes to the Course of Study in order to make English language teaching in schools more 'communicative' (Butler \& Iino, 2005). Like governments the world over, the Japanese government associated English with connectedness to the US-dominated global economy, and so English was placed in a privileged position in comparison with other foreign languages in Japan's national curriculum policy review, the Course of Study. This is revised approximately every ten years. It was in this context that the Japanese government in the first decade of the new century became increasingly concerned by the weaker relative performance of Japanese learners of English in relation to that of comparative learners of English elsewhere in Asia, as was attested to by results in international English language examinations such as TOEIC and TOEFL. As a consequence, and following the examples of China, South Korea and Taiwan, Japan's Ministry of Education, Culture, Sports, Science and Technology (MEXT) announced in the recent Courses of Study that 'English should be taught, in principle, in English' (MEXT, 2009a, 2018). This was a new departure in the Course of Study, and it represented a 
noticeable 'discursive shift' in respect of what had been the hitherto official government stance towards the teaching of English in the Japanese education system, which was to leave it teachers and schools to decide how they wanted to teach the language. The change in pedagogic emphasis generated a great deal of controversy in the press when it was first revealed in 2008, as well as anxiety amongst teachers, who interpreted it as an interference and a threat to their professional practice. Despite opposition to the decision from teachers and the controversy which it generated, the new policy was duly implemented for Japanese senior high schools in April 2013. Following this, in the Course of Study 2017 for junior high schools (MEXT, 2017), to be enacted in 2021, the government announced that the monolingual strategy, just as it appears in the Course of Study 2009 for senior high schools, is to be extended, thus further embedding the move across Japan's national English language curriculum.

In Japanese, there is a word yakudoku (literally, 'translate and read') which originates in the translation activity that facilitated the economic development of Japanese society in the later nineteenth century (Beasley, 1951), and has existed in the discourse of English language schooling in Japan until now (Hiraga, 2005; Seargeant, 2009). Despite this tradition, ELT researchers in Japan have often disparaged yakudoku as an 'old-fashioned' way of teaching and have attempted to find answers as to why Japanese language teachers appear not able to change their practice to a more communication-oriented way of teaching (Gorsuch, 1998, 2001; Nishino \& Watanabe, 2008; Sakui, 2004). For example, they often point to a perceived lack of proficiency amongst Japanese teachers of English, as well as to Japanese conservatism and social constraints. The term yakudoku has taken on quite negative public connotations as a result, to become associated backwardness and outmoded practices. This is despite its close correspondence with Japanese educational traditions concerning the source of pedagogic authority and knowledge which in other contexts and subjects is still 
revered. Instead, the Japanese government has selected to move in a counter-direction and aligned itself and the Course of Study with predominant pedagogic discourses on language learning as these are realised in 'western-centric' models of SLA and TESOL (May, 2014).

Coincidental with the economic downturn of the early 1990s and the entry of Japan's economy into the 'lost decade' which followed, the Japanese government decided to promote a communicative approach and has maintained this attitude ever since. Despite the government's position, yakudoku as a teaching method persists, and remains widely practised in Japanese schools (Kikuchi \& Browne, 2009; Thompson \& Yanagita, 2017). However, yakudoku is in increasing contention with official government policy, particularly as this is relayed through the Course of Study, where the government perspective appears in the form of an instrumentalist ideology which favours monolingualism.

How this ideology is articulated in Japanese language policy is a primary interest of this article. Our focus is the government policy towards Japanese teachers of English in Japanese senior high schools. We wish to show how the ideology of monolingual instrumentalism has, through the Course of Study, been strategically introduced into senior high schools by the Japanese government and how the local practice of yakudoku, or the use of Japanese in the English language classroom, has been marginalised and disfavoured by it. As part of our discussion, and with the intention of promoting debate, we wish to launch a defence of yakudoku as an emblem of micro-level resistance to western-centric assumptions about knowledge formation, and at the macro level of resistance to the pressures of a global political economy which is structurally dominated (in finance, in production, in military power, and in knowledge output) by an anglophone nation, the United States (Strange, 1989). Employing a methodological approach which is derived from critical discourse analysis (Fairclough, 1992, 2003) and from discourse-oriented ethnography (Hornberger \& Johnson, 2007; Johnson, 2011), we explore the process of the dissemination of monolingual 
instrumentalism in the context of Japan. For this purpose, extracts from policy documents, and data from interviews and group discussions with government officials and Japanese teachers of English have been analysed. Most of the data for this article was collected between May and July 2012 for a separate research project (Noda, 2015). It reflects a time when the fuller implementation of the Course of Study 2009 was beginning to be felt in Japanese senior high schools. We feel that it is timely to revisit this data as the Courses of Study for junior and senior high schools (MEXT, 2017, 2018) will be enacted in 2021 and 2022 respectively. Both carry over the same monolingual principle from the Course of Study 2009 and will continue to operate for some time thereafter.

In the proceeding sections, we present a short overview of the literature on the use of L1 and L1 translation in the classroom in as much as this impacts upon and is relevant to yakudoku. This is followed by an outline of the socio-historical context of English and yakudoku in Japan. We then present the details of the data used for this study, the research framework of CDA, and the guidelines for undertaking the linguistic analysis. In the remaining sections, the perceptions of Japanese government officials and teachers as derived from the transcripts are presented according to three levels of analysis: text, discourse practices of distribution, and discourse practices of consumption (Fairclough, 1992, 2003). To conclude, we discuss the data findings and offer some reflections on the future of English language education in Japan.

\section{Use of L1 in the English classroom}

As noted in the previous section, the practice of monolingualism in ELT has predominated for more than a century, and it is really only quite recently that alternative voices referring to a multi- or pluri-lingual turn in language and linguistics have been heard (Canagarajah, 2006;

G. Cook, 2010; V. Cook, 2001; Cummins, 2007; G. Hall \& G. Cook, 2012; Kubota, 2016; Li, 2018; May, 2014). Nevertheless, despite the growing interest in the use of students' L1 in 
ELT, it remains a minority pursuit. G. Hall and G. Cook (2012) have undertaken a comprehensive review of such research from diverse perspectives, incorporating theories of language acquisition and insights from the fields of cognitive linguistics, psycholinguistics, and sociolinguistics. They have also examined teachers' and learners' attitudes. According to their findings, emerging empirical research supports the use of the students' L1 in the classroom. Although the research findings are varied in regard to the appropriate amount of L1, the findings on its functions have been shared by a number of similar studies. Citing Polio \& Duff (1994), G. Hall and G. Cook (2012) summarise the functions of L1 in the language classroom as including:

grammar instruction, classroom management and administration, to demonstrate empathy or show solidarity with the learners, to provide translations for unknown words and to compensate for learners' apparent lack of understanding and in response to learners already speaking in their own language. (p.286)

Even when these aspects of the use of L1 in the classroom are evidenced, as V. Cook (2001) points out, 'distrust of L1' (p.418) appears as profoundly rooted in the literature on classroom practice, especially when it comes to the use of translation, as the multi-billion dollar ELT training industry testifies. V. Cook (2001) states that we should not think of the use of the students' own language as an inferior alternative to the monolingual approach, or as a failing, but take it positively as an effective means for facilitating learning. But in the same article, he also notes that he carefully avoids using the word 'translation' due to the negative connotations it still retains, where the dominant discourse continues to state that classroom translation, as for example it occurs in yakudoku, is a fundamental taboo.

Undoubtedly, English language teachers have been directly affected by this tendency in academic studies in ELT, and in their training as teachers in the profession. Consequently, many report feeling guilty about using L1 (Macaro, 2005). Reviewing research on teacher 
beliefs about the use of L1, Macaro for example finds that a large majority of bilingual teachers regard L1 use as 'unfortunate and regrettable but necessary' (Macaro, 2005, p.68). In addition, many also believe that students who codeswitch in collaborative activities are somehow 'off task', and in the case of adolescents, even 'deviant and disruptive' (Macaro, 2005, p.67). Many also believe that learners should be able to think in the L2 as much as possible. Most researchers would agree, however, that the 'language of thought' among L2 learners, other than those who are the most competent, would of necessity be their L1 (Macaro, 2005, p.68). This persistent discourse, which emanates from the heart of applied linguistic second language research, and which denies to teachers and learners the use of the local L1, has majorly impacted upon ELT contexts globally, including that of Japan.

\section{The Socio-Historical Context of English and Yakudoku in Japan}

Japan however has never been a place where English has been viewed as an essential means of communication. It has been pointed out that fewer than 10 percent of the entire population of Japan use English on a regular basis in the workplace (Sugita, 2004; Terasawa, 2013). As Miura (2000) has also noted, Japan's current linguistic situation can be described as a double monolingualism: that is, there is a monolingual ideology of Japanese for domestic use as well as one of English for external use, which are both employed for nationalistic purposes. Under the influence of these ideologies, Japanese people on the one hand tend to believe that they all speak Japanese in a 'monolingual' and 'monocultural' Japan, in the absence of linguacultural diversity (Heinrich, 2012; Liddicoat, 2013); on the other hand, English is often dominantly taught as the only foreign language in the state school system, being described and accepted by the government and a great mass of the parental middle classes as an 'international lingua franca' which is necessary to the economic interests of the nation (Kubota, 2011b, 2016), and so also to its children. 
The trends in methods in ELT have changed with the times. In the Meiji era (18681912), inside the schools' system, yakudoku was widely practised as a method for teaching English. The main purpose of the English class in this period was to understand the English text, and translation was used for that purpose. In a sense, yakudoku was quite different from the Grammar-Translation Method (hereafter GTM) which was developed in the West in the later nineteenth century. In GTM, translation was used for students to acquire the grammar of a foreign language, and the acquisition of its grammar was a main focus (Hiraga, 2005). Sawamura (1935) explains that yakudoku can be considered as part of translation in a broad sense, but it is better understood as a way of 'construing' text in a strict sense (cited in Hiraga, 2005, p. 16). Hiraga (2005) states that grammar exercises were incorporated into Japanese English language textbooks in around 1912 and these were combined with traditional translation activity. In Hiraga's opinion, this is the format which can be considered as the Japanese style of teaching English which is known as bumpō-yakudoku (literally 'grammar-translate and read') or simply, yakudoku. But as she points out, the term yakudoku is so well-known that its precise definition is rarely discussed, with the result that different people use it with different meanings. For example, for some, it simply means translation from English into Japanese, while for others it is a method for learning grammar and cultural knowledge as well, as is illustrated in the data analysis sections below.

Alongside the traditional teaching of English, new ideas about language teaching were periodically imported from the West. Most notably, the 'Oral Method' was brought in from Britain by Harold Palmer in 1922, and the 'Oral Approach' was introduced from the US by Charles C. Fries in 1956. The two approaches strongly influenced the academic discourse around ELT in Japan until the 1960s (Imura, 2003). Both approaches placed especial importance on the teaching of sounds. Japanese academics and 'advanced' English teachers in this period emphasised the importance of learning sounds as the 'essence of language' or 
the 'essence of linguistics' and advocated this approach as a more 'correct' way of teaching English, as compared to the 'old-fashioned' local teaching methods. Therefore, some aspects of local teaching, such as the emphasis on grammar, or teaching 'juken eigo' (i.e. only specific aspects of English needed for university entrance examinations), were severely criticised as 'incorrect' ways of teaching (Terasawa, 2014). Subsequently, more 'correct' ways of English teaching were imported periodically, and these methods, such as Communicative Language Teaching (CLT), and later, Task-Based Language Teaching (TBLT), have come to underlie the academic approach to ELT in Japan to this day.

Given the structuring in dominance, as we have referred to it, of monolingual instrumentalism in western-centric SLA and TESOL, it is hardly surprising that yakudoku is disparaged by researchers in these areas. Implicit, and sometimes not so implicit, negative attitudes towards yakudoku may be evidenced through the ways in which the practice is described in the literature (Butler, 2011; Gorsuch, 1998, 2001; Kikuchi, 2009; Kikuchi \& Browne, 2009; Nishino \& Watanabe, 2008; Sakui, 2004; Thompson \& Yanagita, 2017). For example, Gorsuch (2001) dubs yakudoku 'an entrenched traditional method of instruction' (pp. 3-4); Nishino and Watanabe (2008) state that many secondary school teachers stick to 'the traditional grammar-translation method' (p. 134); and Kikuchi (2009) refers to yakudoku as 'the old-style teacher-fronted approach' (p. 468). While no doubt well-meaning, they each argue that the problem of English language teaching in Japan lies in the ongoing gap between the continued fossilised practice of yakudoku and, by implication, the government's more forward-looking communication-oriented reforms. The recent Courses of Study are strongly influenced by such academic opinions.

Up to now little has been written, however, about how education policy in Japan has been produced, disseminated and contested by different stakeholders in the local context. It was the purpose of the earlier project from which this article is derived to present a 
contrasting view by examining the Asian context of Japan and the perspectives of interested stakeholders there. These included national and local government officials, as well as local teachers of English who were being positioned by the government as the putative agents of the Course of Study. For the purposes of the empirical dimension of the research, the following questions guided the study:

(1) How is the ideology of monolingual instrumentalism promoted by the Japanese government? And how is it contested by Japanese Teachers of English?

(2) What are the differences in positions on yakudoku among local stakeholders?

\section{Methodology}

Fairclough (1992) states that most discourses correlate with hegemonic struggle in certain institutions. Citing Gramsci (1971), Fairclough sees hegemony as:

leadership as much as domination across the economic, political, cultural and ideological domains of a society [...] Hegemony is about constructing alliances, and integrating rather than simply dominating subordinate classes, through concessions or through ideological means, to win their consent. (Fairclough, 1992, p. 92)

He further notes that, with word meaning, 'a focus of struggle' for hegemony in discourses (Fairclough, 1992, p.236) is often found in the structuring of the meaning of a 'key word', which has either general or local cultural importance in a context.

Following Fairclough's model of CDA, we wish to show how the ideology of monolingual instrumentalism has achieved hegemony by means of the discourses informing English language education in the Japanese school system. We have therefore adopted Fairclough's three-dimensional concept of discourse (Figure 1, Fairclough, 1992) as an analytical frame (see also Woodside-Jiron, 2011). 


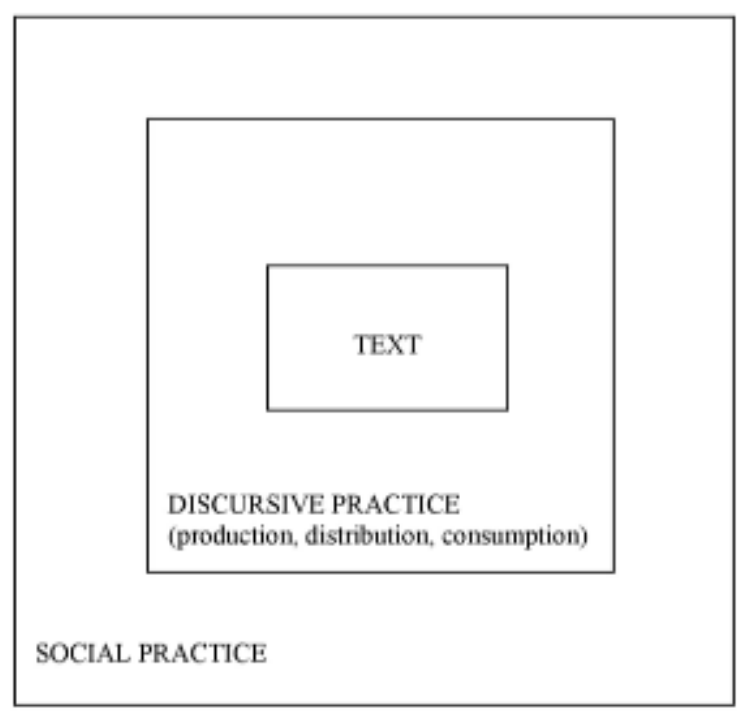

Figure 1. A three-dimensional conception of discourse (Fairclough, 1992, p. 73)

Following this frame, first of all, we analyse text, i.e. language policy in its central existence as written documents. Then, we analyse further discursive practices (hereafter discourse practices), especially aspects of distribution and consumption, by focusing on the ways that the government officials 'work to ensure particular interpretations of text' (Woodside-Jiron, 2011, p. 164) and how teachers in turn, in their social practices, work to resist them.

For the analysis of text, three core governmental policy documents (Gaikokugo Nōryoku no Kōjō ni Kansuru Kentōkai [Commission on the Development of Foreign Language Proficiency], 2011; MEXT, 2009a, 2009b) were selected for identifying the positions of the documents towards monolingual instrumentalism. These texts were originally written in Japanese but some of the parts are also available in English. Thus, the extracts from the policy documents which form part of this study have been translated into English, unless it is stated that the translation is the government's own. For investigating discourse practices, a discourse-oriented ethnography (Hornberger \& Johnson, 2007; Johnson, 2011) 
was adopted. This entailed the utilisation of ethnographic fieldwork strategies (e.g. conducting interviews and group discussions, keeping detailed fieldnotes, and collecting the relevant texts with the purpose of enhancing the discourse analysis). The data were collected between May and July 2012, during visits to MEXT in Tokyo and to a local teacher training centre, in a prefecture in Japan, and a three-week ethnographic field study in three state senior high schools, i.e. for nine weeks in total. The participants were six government officials (three from MEXT and the other three from local government) and twenty-four Japanese teachers of English. While the three MEXT government officials were involved in the policy making and dissemination process, the three local government officials were in charge of the planning and implementation of training for teachers in the prefecture. The schools were considered locally as being low, middle, and high achieving according to a hierarchy which was based on each school's performance in the university entrance examination system, and were deliberately selected. The interviews with both government officials and with teachers were conducted in Japanese and the recordings transcribed. These were then analysed in Japanese, and subsequently translated into English for the purposes of discussion and presentation to a wider audience. Owing to the limitations of space, we have had to be selective in the data which we are able to present, particularly in relation to the interviews, and so only a small portion of this data is presented here.

\section{Text - Policy Documents: the Ideology of Monolingual Instrumentalism}

In this section, we turn our attention to the text of the Course of Study 2009 for senior high schools, which has been carried over into the latest version of 2018 to be enacted in 2022 . The first point of interest is the articulation of MEXT's ideological intention. We see this as initiated in the statement, 'classes, in principle, should be conducted in English' (MEXT 2009a, p. 7, English version). The use of 'in principle' modifies the deontic obligation in a way which would seem to lessen it slightly, by appearing to concede some latitude for not 
conducting classes entirely in English. While this statement is not articulated as an order, we wish to suggest that it nevertheless represents the underlying premise according to which the Course of Study 2009 was framed, as the resultant public controversy around it also indicated (see below). To Japanese teachers of English the statement appeared as a directive, although from the side of the government the phrasing conveniently permitted the deniability that this was the intent. Whichever gloss one places upon it, the encoding (S. Hall, 1990) of a move against yakudoku, and the government's disapproval of this practice, is from a Japanese teachers' perspective strongly implied. For Japanese teachers of English interpreting the guidance, the Course of Study 2009 and its Commentary appeared to present the monolingual classroom as an absolute standard or ideal towards which they should aspire. It is this notion, which the government has done little to deflect, that forms the basis of what we have referred to in this article as the ideological conception of monolingual instrumentalism (see Aizawa \& Rose, 2018; Hashimoto, 2013; Rose \& McKinley, 2018, for related accounts).

When the monolingual proposal for the Course of Study was announced in 2008, this aspect of the new policy received a good deal of attention in the national press. MEXT itself, in its summary of the new Course of Study 2009, singled out 'English-only' classes and the increased amount of vocabulary that learners were now required to learn as two new additions from the 1999 Course of Study (MEXT, n.d. a). Newspapers mainly reported the anxieties which existed among Japanese teachers of English about the policy and questioned whether such a move would be feasible for them. They also suggested that the differences in the attainment levels of pupils in senior high schools would cause different problems for each school. According to the opinions of some teachers, problems would include that less able students would find it impossible to understand the class, particularly at lower-levels and in under-achieving schools. Teachers also expressed the view that it would be difficult to follow the monolingual mandate in higher-level schools, where they were under extreme pressure to 
prepare students for university entrance examinations within a limited amount of time. The result of the new policy was widespread public anxiety among teachers, students and parents.

In the interviews with MEXT government officials, a strong preference for a monolingual instrumental strategy in the classroom is revealed. Let us consider first the most controversial part of the policy text. The text is presented in the original Japanese below and then followed by a standard English translation.

授業は英語で行うことを基本とする。

It is decided that classes, in principle, should be conducted in English.

(Japanese text from MEXT, 2009a, p. 9)

We can examine this excerpt from the perspective of transitivity. According to Fairclough (1992), transitivity is the 'ideational dimension of the grammar of the clause' (p. 177). It relates to 'types of processes which are coded in clauses, and the type of participant involved in them ('participant' here means elements in clauses')' (p. 178). Out of Fairclough's four categories of transitivity processes ('action', 'event', 'relational', and 'mental'), the above statement can be interpreted as a directed action, because writers use the common expression “とする (to suru) [it is decided that]” to give an instruction to readers. In the original Japanese, the topic of the sentence 'classes' is the direct object of the action 'conduct', and the agent is not specified. The omission of the agent can be considered as one of the characteristics of the Japanese language. However, through the interview, it becomes evident that this agent, evidently the teacher, is a focal point of ambiguity in the discourse.

The Course of Study sets out the criteria for organising the education curriculum in Japanese state schools, and its purpose is to maintain a level of educational practice across the country as whole (MEXT, n.d. b). The intended readers of the Course of Study are the school authorities in the school, teachers, and other kinds of educational stakeholders, such as 
staff in relevant local government departments. Therefore, the agent 'teachers' in the sentence is taken to be obvious, and so it is omitted. The readers' general interpretation must be that teachers should, in principle, conduct their classes in English. And in the Commentary, it is seen that the premise is that teachers should speak in English (MEXT, 2009b). This, as noted above, became a source of much anxiety amongst them. In the following interview extract, Government Official A explains this directive as follows.
A: Senior high school teachers first misunderstood it. They thought the classes of yakudoku, if they still do them, should all be done in English. And they thought this was impossible. We agreed with them; of course, it is impossible, as we do not require them to do a yakudoku class in English. We require teachers to make it central that students use English in class, making full use of all the four skills. Therefore, of course teachers should conduct classes in English, as well as students, shouldn't they? It is just that. Nobody is ordering teachers to speak English volubly for fifty minutes.

Here, Government Official A argues that the instruction should be understood differently. His logic is that it is students who should be speaking English more in class, not specifically the teachers; teachers have to help students speak English as facilitators. Here he attempts to justify the monolingual strategy while also seeking to reduce teachers' resistance to the policy, on the grounds that much of the classroom time could be taken up with students speaking, or activating other productive and receptive skills in English. It therefore needs not be a class which is conducted solely through the spoken contribution of the teacher. Importantly, yakudoku is used by the government official to mean something other than 'translation from English to Japanese'. He implies that it means a certain teacher-centred method of teaching by local teachers, as has been commented on by critics, which is in contrast to the way of teaching with language activities which is prescribed in the Course of Study. 
In another interview with Government Official B, first, he emphasises that they do not take it as a given that students may understand English through Japanese. Then he explains the intention of the added instruction in the Commentary as follows.

B: As long as language activities in English play a central part in classes, it might be considered that classes are conducted in a mix of Japanese and English. However, basically, teachers should be persistent in using English. We did not have any perspective here on when to use Japanese effectively.

Researcher (hereafter R): Oh, didn't you have any view on it?

B: No, not at all, only when the necessity arises.

In this interview, it is revealed that MEXT's original intention was to restrict the use of Japanese in the English classroom as much as possible, and therefore the use of Japanese, although it is mentioned in the Commentary, ought not to be interpreted as having official sanction.

\section{Discourse Practice (1) - Government Officials: Yakudoku as Method and as the Use of Students' L1}

This section examines the word meaning (Fairclough, 1992) of yakudoku in the discourse of government officials.

In the discourse of English language education in Japanese senior high schools, the word yakudoku has a local significance, and as we will see, there are different connotations placed upon it which are a source of contestation between speakers. The following data excerpts illustrate how MEXT government officials conceive of yakudoku.

B: A typical example of yakudoku is copying English sentences [from a textbook] on the left side [of a notebook] and writing Japanese sentences on the right side. Teachers have students do this as [homework] preparation and check their translations during the class. 
At that moment, the percentage of students' learning English in the brain is zero. I am very certain it is zero percent, although the ability to manipulate Japanese is enhanced.

Here Government Official B uses the word yakudoku to refer to a teaching and learning pattern centred on translation from English to Japanese, and claims that there is nothing for students to learn from this. The next extract is what another MEXT official explains about a typical learning pattern in an English class.

C: Do you know the worst pattern? Copying a text from a textbook into your notebook. Copying them carefully. Looking up in the dictionary all the meanings of the words and pronunciation symbols and writing them down. If you have time, looking up the example sentences and writing them down. Well, that is not enough. Translate all the English sentences into Japanese. How many hours do you think it takes to do all this?

Government Official C criticises the English teaching practice of local teachers using translation owing to its perceived inefficiency for learning. Officials B and C, who work at a national policy level, admonish what they see as the 'typical' practice of local teachers.

Local government officials, by way of contrast, exhibit a slightly different attitude towards this practice. They also criticise it, as do the MEXT officials, but the level of criticism is more restrained. Note that local officials also employ the term yakudoku to describe the practice or method of teaching.

D: Well, I won't say that putting English into Japanese is all wrong. I also sometimes feel that I understand [the English text] better by replacing it into Japanese, especially when trying to understand a difficult sentence [...] What is not good about yakudoku is that it creates children who always need to understand all the sentences ... To foster children who do not need to understand every sentence, who are satisfied with the gist of text, in this sense, I do not think it is really necessary to do yakudoku. At least, I guess, teachers should stop teaching classes in which they instruct students to translate English sentences and then tell them, 'your translation is wrong'. 
R: So you're not saying that yakudoku is all wrong, but you think the way of doing it was not very good. Or, in other words, you are saying that fussing over small details is not good?

D: Yes. I think there should necessarily be some parts [in English sentences], which are impossible to understand without translating them into Japanese.

Local Government Official D admits that it is sometimes necessary, even for him, to translate English into Japanese when reading English. Then, he points out some of the side-effects of yakudoku as a practice. However, it seems that he does not completely disagree with the teachers' practice, and suggests that teachers should not discourage students from learning English by pointing out their mistakes in translation. Another Local Government Official E talks about yakudoku in a more hesitant manner.

E: Yakudoku. Well, if a subject whose objective is to translate English into Japanese exists ... To translate English into Japanese is not given as a purpose, so if that is the purpose of a class, the class is not fine. So, students write all the translated sentences in the notebook and teachers correct them, and then go on to the next lesson, this procedure is not good. Well, even if a teacher decides that translation is necessary, I think it is difficult to make it central to a class. Teachers have to think how they enable students to use that knowledge in verbal activities, after the translation. Well, especially, when a new sentence structure appears in a text, it can be easier to understand it by making a comparison between English and Japanese. Well, in that sense, teaching [with translation] can happen, I suppose.

In this extract, it is observed that, like Local Government Official D, Local Government Official E also seems to admit the possibility of translation and suggests that translation can be part of classroom practice, although he implies that a certain manner of teaching which involves an excessive focus on translation should be avoided.

From the foregoing, it can be seen that on the one hand, MEXT government officials appear to take a highly critical stance towards yakudoku both as the use of the students' L1 
and as a traditional classroom format, or method, which is centred on the translation of a written text from English to Japanese. They take these together as constituting an ineffective mode of teaching and wish to promote a more monolingually-oriented strategy in its place. On the other hand, local government officials can be seen not completely to deny yakudoku in the form of students' L1 use in class, although like the MEXT officials, they are critical of it as a method. The reason for such a difference existing between the two levels of government officials may possibly be explained by the proximity of the national government officials to dominant academic discourses about second language learning, and the proximity of the local government officials to actual teachers and their teaching practice. Due to their preoccupation with academic perspectives largely emanating from the anglophone core, the national government officials take a more instrumentalist view. This has in turn been transferred to the Course of Study and further projected onto local teachers, whose practice of yakudoku has been a focus of longstanding official disapproval and criticism. In the next section, the local teachers' perspective is presented.

\section{Discourse Practice (2) - Teacher Anxiety and Resistance}

Here we explore the perspective of local teachers and what their discourse reveals concerning their roles as consumers as well as agents of the Course of Study and of yakudoku. From the data, it is found that teachers resist the ideology of monolingual instrumentalism which is implied in the policy documentation. While none of them reject yakudoku as the use of the students' $L 1$, they do reflect critically on yakudoku as a method. We asked what teachers thought they were expected to do through the Course of Study. In response, they told of their experiences of government training courses which were designed to assist teachers in implementing the policy.

F: They tell us to conduct classes in English in principle. I have taken some training in $\mathrm{X}$ area, and I saw teachers conduct classes all in English [...] I saw a teacher making a lot 
of effort to explain the meaning of a word in simple English. But I wondered if we should spend such a time for that. I think it all depends. We should divide when we conduct a class in English and when we explain a difficult grammatical thing clearly in Japanese. I think now all is mixed up and we are told to do everything in English [...] I am worried that students who do not understand the class well will be left behind if we do so. We may end up telling students to study by themselves [...] I do not have any hesitation to change [...] But if we should do everything all in English, I think we will come to a dead end.

From this interview passage, we learn that Teacher $\mathrm{F}$ had received training in the local area and observed a model class which conformed to the new policy, i.e. a class that was entirely conducted in English. But he expresses doubts over whether it is really a more efficient way of teaching for his students and worries about its negative effects.

In the following lines, we present select extracts that include references to yakudoku, in order to explore teachers' reactions to the term. In their interviews, some teachers expressed critical opinions regarding making translation a central activity in a class.

G: I am not against doing yakudoku itself. I can understand students find it easy to understand when English is put into Japanese. Well, I am not against it, but I do not find it good when doing yakudoku becomes an objective. When they put English into Japanese, they feel, 'that's it'.

$\mathrm{H}$ : People criticise yakudoku when students dictate Japanese translation, and say it is not an English class. As a result of trying to understand English sentences precisely, there is a moment when the Japanese language replaces English in English classes, and that is when teachers are criticised.

Teacher $\mathrm{G}$ points out, in a similar way as the local government officials in the previous section, that students appear to be satisfied with themselves when they are able to translate an English text into Japanese, as though that were sufficient. Teacher $\mathrm{H}$ finds it problematic that many teachers use Japanese language predominantly in their English class in making the effort to have students understand the English text precisely. Both of them are aware of the 
problems of using translation as a central activity. This then, raises the issue as to why teachers like $\mathrm{G}$ and $\mathrm{H}$ persist with it. The following observations of Teacher I and $\mathrm{F}$ may be indicative of an answer. According to them, yakudoku is interpreted in a too limited way. The use of the students' L1 can positively help students in their understanding of English.

I: I think there are various patterns even when we use translation, or yakudoku. Yes. Some teachers drone on in Japanese on their own, but I think it is possible to have students think in a proactive way. So, it is erroneous to bracket this together as yakudoku. Yakudoku should not immediately imply a 'bad' practice. It can be an effective way depending on how teachers interpret it and whether they use it in a creative way. The harder the content becomes, the more difficult it is to understand it in English. So, in order to have students understand the structure, we teachers give hints so that students can notice it. To do this, we need to go through Japanese. Well, I hate the word yakudoku, because it brackets everything together. There are many ways of teaching and there is a way of going through Japanese, and I think it is enough if teachers teach creatively. So, it is wrong to bracket these things together! It is really nonsense.

F: Well, I agree with Mr. I or, I should say, I feel in the same way. It is said that yakudoku is bad because it replaces English with Japanese. But it is not like that. It is comprehension. The harder the content is $[\ldots]$ the better we can understand it in Japanese. In that sense, especially where we cannot understand without really understanding the structure, $[\ldots]$ we should be able to use Japanese as an aid, and I believe that leads to students' better understanding.

Teacher I is aware that 'yakudoku' has a derogatory connotation and rewords it as 'translation'. He says using yakudoku or translation is an effective method for teaching English and it can be used in different ways. One of the cases when Japanese is involved, which is given by both Teachers I and F, is when teachers attempt to assist students' comprehension of difficult sentence structures. They argue that this aspect of yakudoku seems to be overlooked, as all the practices of teaching with translation are bracketed together within the derogatory term yakudoku. Hence, from this it can be seen that while teachers critically reflect upon yakudoku as a method, they do not reject the use of translation or the 
students' L1 as a means of teaching in the classroom. They also promote what they see as yakudoku's value for the development of bilingualism and an appreciation of other languages and cultures.

\section{Conclusion: Implications for the Future}

In this article, we have analysed the ways in which, under the influence of SLA and TESOL perspectives on language acquisition and pedagogy, an ideology of monolingual instrumentalism has been promoted by the Japanese authorities. We have also illustrated how this ideology has an implicit hegemony in the language of the Course of Study. Secondly, we have given an account of the differences in perceptions of yakudoku amongst diverse educational stakeholders in government (local and national) and in schools. In the dimension of text, we have identified that a focal point of ambiguity in the Course of Study is the absent agent who conducts the classes. As the analysis of the document shows, the agent that is to conduct English classes in English is not specified, but can be strongly assumed to be Japanese teachers of English. Despite this, it has been found that the government officials, as disseminators of the policy, argue - in a reframing of the Course of Study instruction - that it is students who should be encouraged to take the lead in English language activities in class, not teachers, so as to reduce the amount of time teachers spend directing the class, and presumably also to lessen their grounds for opposition. From the interviews it is revealed that MEXT government officials have a strong preference for a more monolingual teaching strategy and see little value in the use of Japanese L1 in the classroom. Government Official $\mathrm{B}$, for example, dismisses yakudoku, on the basis that 'the percentage of students' learning English in the brain is zero', and Government Official C disparages the time yakudoku consumes. Some others, such as Officials D and E are more ambivalent, but on the whole come down on the side of an instrumentalist approach. 
In the next dimension of discourse practices on the part of government officials as well as teachers, we have found out that both groups tend to talk about yakudoku as a method, rather than simply as the use of students' L1. In the data, it is also seen that there is a difference between the government officials at the national level and the ones at the local level, in the manner in which they criticise yakudoku. While the government officials at the national level view it as a method and entirely disapprove of yakudoku, the ones at local level criticise it as a method but are more accepting of it when it is conceived as the use of students' L1. As mentioned earlier, this difference may be explained by the proximity of the respective stakeholders to dominant academic discourses concerning SLA and TESOL. The further their positions are from the language classroom on the ground, the more they are likely to gravitate towards an instrumentalist view, whereas the closer they are to actual classrooms and teachers, the more tolerant of yakudoku they are likely to be. In debates over English language pedagogy and second language acquisition globally it has tended to be the instrumentalist perspective which has emerged as structured in dominance within academic domains. This in turn has had an impact upon Japanese government policy as it has sought to sustain the modernisation of Japan in the face of growing external economic competition, while also remaining engaged with a US-dominated world-system where English is the global lingua franca, and where the sphere of international knowledge production is also dominated by English. The dominance of the US in the world economy, particularly after 1945, alongside American direction of the post-war reconstitution of Japan, and the subsequent rise and decline in Japanese economic fortunes thereafter, have been singular influences in the tendency to privilege western-centric knowledge and ideas over local ones. As noted in this article, this tendency has fed into Japanese ELT, with the result that local ELT practice is often cast as 'ineffective' while new pedagogies emanating from the anglophone core are viewed as 'more effective'. In this way, an attitude of monolingual 
instrumentalism has become entrenched in government perspectives and been materialised in the Course of Study.

It is understood from the data that teachers find it more and more difficult to justify their use of L1 in the English classroom despite their being aware of its usefulness. From the teachers' remarks, it can be seen that they are placed in a difficult position by being pressured - as they see it - by the government only to use English in the classroom. We suggest that the term yakudoku has become both 'a mode of hegemony and a focus of struggle' for teachers (Fairclough, 1992, p. 238). It is a mode of hegemony, because its derogatory connotations marginalise and subjugate teachers (V. Cook, 2001; Macaro, 2005). It is a focus of struggle, because it is understood in different ways by the different stakeholder groups of this study in their struggles with one another over policy.

We argue that the ideology of monolingual instrumentalism and the hegemonic struggle over the use of L1 in the Japanese ELT classroom have had the effect of distorting local teaching practice in schools. The 'dominance of the monolingual assumption' (G. Hall \& G. Cook, 2012, p. 273) not only inhibits teachers from making efforts to improve teaching practice in a sound and locally-appropriate manner, but it also prevents 'the development of bilingual and bicultural identities and skills that are actively needed by most learners, both within the English-speaking countries and in the world at large' (p. 273), and which a sensitive use of yakudoku provides.

It is also our view that what is crucially needed is to distinguish clearly the practice of yakudoku as a method from the classroom use of $L 1$ in order to bring about a change in the discourse. First of all, researchers on English teaching practice in Japan have to be made aware of their bias with regard to yakudoku as a method. They tend to seek out the specific factors which prevent teachers from abandoning yakudoku as a method and moving to a more communicative approach (Gorsuch, 1998, 2001; Nishino \& Watanabe, 2008; Sakui, 2004). 
But this attitude deprives teachers of their confidence and leads to the suppression of their use of the L1. More research also needs to be done on bilingual materials and translation practices. In so doing, researchers may reveal what kinds of bilingual modes of learning exist and what the most effective ways are for doing it. As Butler (2011) notes, now is the time to come up with more localised, contextualised ways of teaching.

At the policy level, the Japanese government should first eliminate from the Course of Study the initiating statement which suggests the imposition of a monolingual strategy upon teachers, and which has been widely interpreted by teachers in this way. In addition, government officials must make more efforts to enhance teachers' as well as students' positive views towards bi/multi-lingual speakers in teacher training (Li, 2018; May, 2014), rather than by their inaction giving credence to the belief that they wish to transform teachers into monolingual English speakers in the classroom through their deliberate undermining of yakudoku. For this to happen, we need to start by challenging the bias against translation which at the micro level continues to be structured in dominance in English language pedagogic theory, and which is sustained at the macro level by the global anglophone hegemony in the world economy and system.

\section{References}

Aizawa, I., \& Rose, H. (2018). An analysis of Japan's English as medium of instruction initiatives within higher education: The gap between meso-level policy and microlevel practice. Higher Education. doi:10.1007/s10734-018-0323-5

Althusser, L. (1996). For Marx. London, UK: Verso. (Original work published 1965)

Beasley, W. G. (1951). Great Britain and the opening of Japan 1834-1858. London, UK: Luzac \& Company. 
Butler, Y. G. (2011). The implementation of communicative and task-based language teaching in the Asia-Pacific region. Annual Review of Applied Linguistics, 31, 36-57. doi:10.1017/S0267190511000122

Butler, Y. G., \& Iino, M. (2005). Current Japanese reforms in English language education: The 2003 “action plan”. Language Policy, 4(1), 25-45.

Canagarajah, A. S. (2006). TESOL at forty: What are the issues? TESOL Quarterly, 40(1), 934. doi:10.2307/40264509

Cook, G. (2010). Translation in language teaching: An argument for reassessment. Oxford, UK: Oxford University Press.

Cook, V. (2001). Using the first language in the classroom. Canadian Modern Language Review, 57(3), 402-423. doi:10.3138/cmlr.57.3.402

Cummins, J. (2007). Rethinking monolingual instructional strategies in multilingual classrooms. Canadian Journal of Applied Linguistics, 10(2), 221-240.

Fairclough, N. (1992). Discourse and social change. Cambridge, UK: Polity Press.

Fairclough, N. (2003). Analysing discourse: Textual analysis for social research. London, UK: Routledge.

Gaikokugo Nōryoku no Kōjō ni Kansuru Kentōkai [Commission on the Development of Foreign Language Proficiency]. (2011, June 30). Kokusai kyōtsūgo toshite no eigoryoku kōjō no tame no 5tsu no teigen to gutaiteki shisaku [Five proposals and specific measures for developing proficiency in English for international communication]. Retrieved from http://www.mext.go.jp/b_menu/shingi/chousa/shotou/082/houkoku/1308375.htm

Gorsuch, G. (1998). Yakudoku EFL instruction in two Japanese high school classrooms: An exploratory study. JALT Journal, 20(1), 6-32. Retrieved from http://jaltpublications.org/jj 
Gorsuch, G. (2001). Japanese EFL teachers' perceptions of communicative, audiolingual and yakudoku activities: The plan versus the reality. Education Policy Analysis Archives, 9(10), 1-27. doi:10.14507/epaa.v9n10.2001

Gramsci, A. (1971). Selections from the Prison Notebooks. Q. Hoare \& G. Nowell Smith (Eds.). London, UK: Lawrence and Wishart.

Hall, G., \& Cook, G. (2012). Own-language use in language teaching and learning. Language Teaching, 45(3), 271-308. doi:10.1017/S0261444812000067

Hall, S. (1990). Encoding/decoding. In S. Hall, D. Hobson, A. Lowe \& P. Willis (Eds.), Culture, media, language (pp. 128-138). London, UK: Unwin Hyman.

Hashimoto, K. (2013). 'English-only', but not a medium-of-instruction policy: The Japanese way of internationalising education for both domestic and overseas students. Current Issues in Language Planning, 14(1), 16-33. doi:10.1080/14664208.2013.789956

Heinrich, P. (2012). The making of monolingual Japan: Language ideology and Japanese modernity. Bristol, UK: Multilingual Matters.

Higuchi, T., Izumi, E., Kinugasa, T., Kagada, T., Tanabe, Y., Kakeya, M., ... Fujita, N. (2005). Shogaikoku no gengo kyōiku seisaku to nihon no gaikokugo kyōiku eno shisa [Language education policy in different countries and implications for foreign language education in Japan]. Kinki University Department of Language Education Journal, 1, 1-61. Retrieved from http://id.nii.ac.jp/1391/00013756/

Hiraga, Y. (2005). 'Bumpō-yakudoku shiki kyōjuhō' no teigi saikō [Re-thinking about the definition of 'bumpō-yakudoku teaching method']. Nihon Eigo Kyōikushi Kenkyū [Research on History of English Language Education in Japan], 20, 7-26. doi:10.11222/hisetjournal1986.20.0_7 
Hornberger, N. H., \& Johnson, D. C. (2007). Slicing the onion ethnographically: Layers and spaces in multilingual language education policy and practice. TESOL Quarterly, 41(3), 509-532. doi:10.1002/j.1545-7249.2007.tb00083.x

Imura, M. (2003). Nihon no eigo kyöiku 200 nen [A two-hundred year history of English language teaching in Japan]. Tokyo, Japan: Taishukan.

Johnson, D. C. (2011). Critical discourse analysis and the ethnography of language policy. Critical Discourse Studies, 8(4), 267-279. doi:10.1080/17405904.2011.601636

Kikuchi, K. (2009). Listening to our learners' voices: What demotivates Japanese high school students? Language Teaching Research, 13(4), 453-471. doi:10.1177\%2F1362168809341520

Kikuchi, K., \& Browne, C. (2009). English educational policy for high schools in Japan: Ideals vs. reality. RELC Journal, 40(2), 172-191. doi:10.1177\%2F0033688209105865

Kubota, R. (2011a). Questioning linguistic instrumentalism: English, neoliberalism, and language tests in Japan. Linguistics and Education, 22(3), 248-260. doi:10.1016/j.linged.2011.02.002

Kubota, R. (2011b). The politics of school curriculum and assessment in Japan. In Y. Zhao, J. Lei, G. Li, M. F. He, K. Okano, N. Megahed, ...H. Ramanathan (Eds.), Handbook of Asian education: A cultural perspective (pp. 214-230). London, UK: Routledge.

Kubota, R. (2016). Neoliberal paradoxes of language learning: Xenophobia and international communication. Journal of Multilingual and Multicultural Development, 37(5), 1-14. doi:10.1080/01434632.2015.1071825

Liu, D., Ahn, G.-S., Baek, K.-S., \& Han, N.-O. (2004). South Korean high school English teachers' code switching: Questions and challenges in the drive for maximal use of English in teaching. TESOL Quarterly, 38(4), 605-638. doi:10.2307/3588282 
Li, W. (2018). Translanguaging as a practical theory of language. Applied Linguistics, 39(1), 9-30. doi:10.1093/applin/amx044

Liddicoat, A. J. (2013). Language-in-education policies: The discursive construction of intercultural relations. Bristol, UK: Multilingual Matters.

Macaro, E. (2005). Codeswitching in the L2 classroom: A communication and learning strategy. In E. Llurda (Ed.), Non-native language teachers: Perceptions, challenges, and contributions to the profession (Vol. 5, pp. 63-84). Boston, MA: Springer US.

May, S. (2011). The disciplinary constraints of SLA and TESOL: Additive bilingualism and second language acquisition, teaching and learning. Linguistics and Education, 22(3), 233-247. doi:10.1016/j.linged.2011.02.001

May, S. (2014). Disciplinary divides, knowledge construction, and the multilingual turn. In S. May (Ed.), The multilingual turn: Implications for SLA, TESOL and bilingual education (pp. 7-31). Oxon, UK: Routledge.

Ministry of Education Culture Sports Science and Technology (MEXT). (2009a). Kōtōgakkō gakushū shidō yōryō [Course of Study for Upper Secondary Schools]. Retrieved from http://www.mext.go.jp/a_menu/shotou/new-cs/youryou/index.htm

Ministry of Education Culture Sports Science and Technology (MEXT). (2009b). Kōtōgakkō gakushū shidō yōryō kaisetsu: gaikokugohen/eigo hen [Commentary on the Course of Study for Upper Secondary Schools: Foreign languages/English]. Retrieved from http://www.mext.go.jp/a_menu/shotou/new-cs/youryou/index.htm

Ministry of Education Culture Sports Science and Technology (MEXT). (2017). Chūgakkō gakushū shidō yōryō [Course of Study for Lower Secondary Schools]. Retrieved from http://www.mext.go.jp/a_menu/shotou/new-cs/youryou/index.htm 
Ministry of Education Culture Sports Science and Technology (MEXT). (2018). Kōtōgakkō gakushū shidō yōryō [Course of Study for Upper Secondary Schools]. Retrieved from http://www.mext.go.jp/a_menu/shotou/new-cs/1384661.htm

Ministry of Education Culture Sports Science and Technology (MEXT). (n.d. a). Kōtōgakkō gakushū shidō yōryō: kaitei no pointo [Course of Study for Upper Secondary Schools: Revision highlights]. Retrieved from http://www.mext.go.jp/a_menu/shotou/newcs/youryou/1304427.htm

Ministry of Education Culture Sports Science and Technology (MEXT). (n.d. b). Gakushū shidō yōryō: ikiru chikara [Course of Study: Zest for Life]. Retrieved from http://www.mext.go.jp/a_menu/shotou/new-cs/index.htm

Miura, N. (2000). Shokuminchi jidai to posuto-shokuminchi jidai no gengo shihai [The control over languages in the colonial and post-colonial eras]. In N. Miura \& K. Kasuya (Eds.), Gengo teikoku-shugi to wa nanika [What is linguistic imperialism?] (pp.6-24). Tokyo, Japan: Fujiwara Shoten.

Nishino, T., \& Watanabe, M. (2008). Communication-oriented policies versus classroom realities in Japan. TESOL Quarterly, 42(1), 133-138. doi:10.1002/j.15457249.2008.tb00214.x

Noda, M. (2015). A discourse-ethnographic investigation into foreign language teaching policy for Japanese senior high schools. (Unpublished doctoral dissertation). UCL Institute of Education, University College London. London, UK.

Polio, C., \& Duff, P. (1994). Teachers' language use in university foreign language classrooms: A qualitative analysis of English and target language alternation. The Modern Language Journal, 78(3), 313-326. doi:10.1111/j.1540-4781.1994.tb02045.x 
Rose, H., \& McKinley, J. (2018). Japan's English-medium instruction initiatives and the globalization of higher education. Higher Education, 75(1), 111-129. doi:10.1007/s10734-017-0125-1

Sakui, K. (2004). Wearing two pairs of shoes: Language teaching in Japan. ELT Journal, 58(2), 155-163. doi:10.1093/elt/58.2.155

Sawamura, T. (1935). Yakudoku to honyaku [Yakudoku and translation]. Tokyo, Japan: Kenkyusha.

Seargeant, P. (2009). The idea of English in Japan: Ideology and the evolution of a global language. Clevedon, UK: Multilingual Matters.

Strange, S. (1989). Toward a theory of transnational empire. In E. O. Czempiel \& J. N. Rosenau (Eds.), Global changes and theoretical challenges: Approaches to world politics for the 1990s (pp. 161-176). Lexington, Mass.: Lexington Books.

Sugita, H. (2004). The effects of English learning experience on Japanese people's English conversation ability: From the data of JGSS-2002. Japanese General Social Surveys (JGSS): Collection of research papers, 3, 45-57. Retrieved from http://jgss.daishodai.ac.jp/english/research/res_top.html\#3

Terasawa, T. (2013). “Ninety percent of Japanese do not need English”?: Statistical analysis of workers' needs to use English. KATE Journal, 27, 71-83. doi:10.20806/katejournal.27.0_71

Terasawa, T. (2014). 'Nande eigo yaru no?' no sengoshi: 'Kokumin kyōiku' toshite no eigo, sono dentō no seiritsu katei [The post-war history of 'Why do we learn English?': The process of establishment of tradition of English as 'national education"]. Tokyo, Japan: Kenkyusha. 
Thompson, G., \& Yanagita, M. (2017). Backward yakudoku: An attempt to implement CLT at a Japanese high school. Innovation in Language Learning and Teaching, 11(2), 177-187. doi:10.1080/17501229.2015.1088856

van Splunder, F. (2016). Language ideologies regarding English-medium instruction in European higher education: Insights from Flanders and Finland. In E. W. Barakos \& J. Unger (Eds.), Discursive approaches to language policy (pp. 205-230). London, UK: Palgrave Macmillan.

Woodside-Jiron, H. (2011). Language, power and participation: Using critical discourse analysis to make sense of public policy. In R. Rogers (Ed.), An introduction to critical discourse analysis in education (2nd ed., pp. 154-182). London, UK: Routledge. 